\title{
A perspective on differences in soil properties between organic and conventional farming in dairy and sheep and beef sectors
}

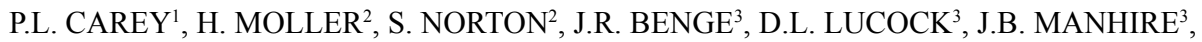 \\ E.D. MEENKEN ${ }^{4}$ and S. JIANG ${ }^{1}$ \\ ${ }^{1}$ Land Research Services Ltd, PO Box 84, Lincoln University \\ ${ }^{2}$ Centre for the Study of Agriculture, Food and the Environment, University of Otago \\ ${ }^{3}$ Agribusiness Group Ltd., Christchurch \\ ${ }^{4}$ Plant and Food Research, Canterbury Agricultural and Science Centre, Lincoln \\ peter@1rss.co.nz
}

\begin{abstract}
The Agricultural Research Group on Sustainability (ARGOS) has been comparing soil quality between conventional, organic and alternative management systems for New Zealand sheep and beef (SB) and dairy (DY) sectors. The relative intensity of each sector was calculated from energy inputs (/ha) and energy return on investment values (ranked $\mathrm{SB}<\mathrm{DY}$ ). A simple null hypothesis was formed that there were no differences between different management systems, irrespective of the intensity of the sector. Of the 25 soil properties measured, $\mathrm{P}, \mathrm{S}, \mathrm{pH}$, cation exchange capacity (CEC), exchangeable- $\mathrm{Mg}, \mathrm{C} / \mathrm{N}$ ratio, earthworm numbers, basal-respiration and soil microbial biomass-C were significantly different at the management level. CEC, exchangeable-Ca, BS\% and anaerobic mineralisable-N were significant at the sector-by-management interaction level i.e. there were few differences in management system with a difference in sector intensity. Most variation in soil properties between sectors and management could be attributed to soil order and landuse effects rather than management effects.
\end{abstract}

Keywords: energy usage, soil test, pastoral

\section{Introduction}

The New Zealand Agriculture Research Group On Sustainability (ARGOS) has been investigating soil quality since 2004 on sheep and beef (SB), dairy (DY) and kiwifruit (KF) sectors. A major part of any comparison of sustainability and resilience between agricultural production systems is soil quality and whether an organic system produces fewer deleterious effects than a "conventional" system. The back-drop to this question is the intensity of the farming in the primary sector and whether dairying could exacerbate such effects and reduce the soil's biological function than a more extensive sector like sheep and beef. We set out to test a simple null hypothesis that there are no differences in soil properties between management systems for all production sectors. We present data for the SB and DY sectors.

\section{Materials and Methods}

\section{Research design}

The ARGOS programme concentrated on establishing groups (clusters) of commercial farms that were under the target management systems and in close proximity to ensure soils, topography and climate were similar within clusters. Soil sampling was conducted from randomly chosen permanent soil monitoring sites (SMS) but from within the dominant landforms identified for each farm. For flat farms only one landform was sampled whilst for hill farms, slope, flat and crest landforms might be sampled. This approach was used to mitigate the effects of large spatial variability within the farms, and individual paddocks formed the minimum management unit (MU).

\section{Primary sectors}

For each sector, 12 clusters of farms were monitored. Each SB cluster consisted of an organic farm with a matched integrated and conventional counterpart (i.e. a total of 36 farms) whilst each DY cluster consists of an organic farm matched with a conventional counterpart (i.e. a total of 24 farms). The 12 farms under each management system constituted a panel.

For SB, all 12 clusters were located throughout the South Island from Marlborough to Southland whilst for DY the 12 clusters were all located in the North Island in the Waikato (4), Taranaki (3), Manawatu (3), Coromandel (one at Waihi) and Auckland (one at Pukekohe) regions. Whilst this meant that there was potentially large inherent variation between the sectors, there was also a similar range in variation between clusters of an individual sector and both could be accommodated within the statistical analysis (Table 1).

\section{Management system}

The organic farms in this study all used accredited organic production protocols and have achieved organic accreditation status although at the time of the initial sampling half of the dairy farms were still undertaking the accreditation process (2-3 years). 
Table 1 Region, mean property size, soil classification and horizon depth (A \& B) for sheep and beef and dairy sector clusters.

\begin{tabular}{|c|c|c|c|c|c|c|}
\hline \multirow[t]{2}{*}{ Cluster } & \multirow[t]{2}{*}{${ }^{1}$ Region } & Av. area & \multirow[t]{2}{*}{ Aspect } & \multicolumn{2}{|c|}{ Av. soil depth } & \multirow{2}{*}{$\begin{array}{c}{ }^{2} \mathrm{NZ} \text { Soil } \\
\text { Order }\end{array}$} \\
\hline & & (ha) & & & B & \\
\hline \multicolumn{7}{|c|}{ Sheep \& Beef } \\
\hline 1 & MAR & 422 & hill & 18 & 31 & $\mathrm{P} / \mathrm{Br}$ \\
\hline 2 & NCT & 583 & hill & 27 & 29 & $\mathrm{P} / \mathrm{M}$ \\
\hline 3 & BKP & 315 & hill & 22 & 40 & $\mathrm{P} / \mathrm{Br}$ \\
\hline 4 & MCT & 408 & flat & 19 & 24 & $P / G$ \\
\hline 5 & MCT & 393 & flat & 25 & 42 & $\mathrm{R} / \mathrm{Br}$ \\
\hline 6 & MCT & 280 & flat & 20 & 16 & $\mathrm{R} / \mathrm{Br}$ \\
\hline 7 & SCT & 474 & hill & 23 & 32 & $\mathrm{Br}$ \\
\hline 8 & SOT & 849 & hill & 18 & 36 & $\mathrm{Br}$ \\
\hline 9 & CAT & 491 & hill & 23 & 39 & $\mathrm{Br}$ \\
\hline 10 & SLD & 298 & hill & 26 & 30 & $\mathrm{P} / \mathrm{U} / \mathrm{M}$ \\
\hline 11 & NOT & 794 & hill & 27 & 38 & $\mathrm{P}$ \\
\hline 12 & SCT & 238 & hill & 23 & 27 & $P$ \\
\hline Mean & & 462 & & 23 & 32 & \\
\hline \multicolumn{7}{|l|}{ Dairy } \\
\hline 1 & WAI & 96 & hill & 23 & 45 & A \\
\hline 2 & WAI & 50 & hill & 20 & 52 & A \\
\hline 3 & WAI & 89 & flat & 18 & 47 & $A$ \\
\hline 4 & WAI & 167 & hill & 25 & 53 & $A$ \\
\hline 5 & COR & 100 & hill & 26 & 57 & $\mathrm{~A} / \mathrm{Br}$ \\
\hline 6 & TAR & 102 & flat & 27 & 48 & A \\
\hline 7 & TAR & 84 & flat & 19 & 46 & $A$ \\
\hline 8 & TAR & 109 & flat & 22 & 42 & A \\
\hline 9 & MAN & 150 & flat & 24 & 47 & $\mathrm{Gl} / \mathrm{R}$ \\
\hline 10 & AUK & 133 & flat & 21 & 49 & A \\
\hline 11 & MAN & 93 & hill & 20 & 38 & $\mathrm{Gl}$ \\
\hline 12 & MAN & 445 & flat & 18 & 45 & $\mathrm{Gl} / \mathrm{R}$ \\
\hline Mean & & 135 & & 22 & 47 & \\
\hline
\end{tabular}

${ }^{1}$ Region key: AUK= Auckland, BKP=Banks Peninsula, MCT= Mid-Canterbury; NCT= North-Canterbury, SCT= South-Canterbury, CAT $=$ Catlins, NOT $=$ North Otago, SOT $=$ South Otago, SLD = Southland, WAI $=$ Waikato, TAR= Taranaki, COR= Coromandel, MAN= Manawatu; ${ }^{2}$ Dominant soil types for SMS in cluster farms or orchards. Key to NZ soil order: $A=A l l o p h a n i c, B r=B r o w n$, $\mathrm{Gl}=$ Gley, $\mathrm{P}=$ Pallic, $\mathrm{M}=$ Melanic, $\mathrm{R}=$ Recent, $\mathrm{U}=$ Ultic,

The integrated farms were complying with a quality assurance programme that involves production under some management constraints to produce animals for a targeted market specification. The programme usually reduced pesticide and herbicide use, with higher environmental performance and/or animal welfare standards (Coetzer 2010). Conventional represents comparable farms not specifically using these or organic protocols.

Organic properties for SB had an average age of 11 years but DY properties, as an establishing organic sector, had an average age of only 6 years. Integrated (SB) farms also had an average age of 6 years.

\section{Energy flows}

Comprehensive energy usage values were compiled for each sector from a number of ARGOS reports and other sources that previously provided a detailed resource inventory for each panel (Barber \& Lucock 2006; Barber et al. 2008; Wells 2001). Energy embodied in outputs (i.e. products) included meat, wool, milksolids (MS) and any exported crop whilst energy inputs per 
Table 2 Median and (inter-quartile range) for energy outputs, inputs, energy return on investment (EROI) ratio, stocking rates and fertiliser energy use for all sector panels (2002/2003-2008/2009).

\begin{tabular}{lccccc}
\hline Term & \multicolumn{3}{c}{ Sheep and Beef ${ }^{1}$} & \multicolumn{3}{c}{ Dairy $^{2}$} \\
& Conv. & Integ. & Org. & Conv. & Org. \\
\hline Outputs & 2.2 & 1.9 & 1.6 & 34.3 & 15.6 \\
(GJ/ha/y) & $(1.7-2.4)$ & $(1.6-3.0)$ & $(1.4-2.1)$ & $(28.7-38.1)$ & $(12.8-21.6)$ \\
Inputs & 3.7 & 4.2 & 2.8 & 9.8 & 6.8 \\
(GJ/ha/y) & $(3.2-4.6)$ & $(3.2-9.0)$ & $(2.2-3.4)$ & $(6.0-11.9)$ & $(3.0-8.6)$ \\
EROI ratio & 0.36 & 0.38 & 0.36 & 3.5 & 3.0 \\
& $(0.33-0.40)$ & $(0.23-0.56)$ & $(0.25-0.46)$ & $(2.8-4.9)$ & $(2.6-3.9)$ \\
Stock units (/ha) & 10.3 & 10.8 & 8.6 & 20.8 & 12.4 \\
& $(8.7-12.7)$ & $(7.9-14.1)$ & $(7.1-9.6)$ & $(18.5-23.1)$ & $(8.0-15.3)$ \\
${ }^{3}$ Fertiliser & 1.9 & 2.0 & 0.7 & 8.0 & 2.0 \\
(GJ/ha/y) & $(1.4-2.4)$ & $(1.4-4.2)$ & $(0.4-1.0)$ & $(4.6-10.2)$ & $(1.5-5.7)$ \\
\hline
\end{tabular}

${ }^{1}$ Sheep and beef inputs were fertiliser, electricity, supplementary feed, agrichemicals, animal remedies, and capital items including buildings and machinery, fences, and races. Outputs were animals as liveweight leaving the farm, wool, and crops harvested; ${ }^{2}$ Dairy inputs were fertiliser, electricity and supplementary feed. Outputs were milksolids and cull cows; ${ }^{3}$ total annual fertiliser energy use ( $N, P, K$ and $S$ ).

hectare (GJ/ha) for SB included fuel and electricity plus the embodied energy in fertiliser, agrichemicals and capital items and for DY fertiliser, electricity and supplementary feed (Table 2). From these, energy return on investment values (EROI) could be calculated for each sector and management system. Further details on how these were calculated and their sources are included in Norton et al. (2010, this volume).

\section{Soil measurements}

Within each management unit (paddock or block), three SMS were randomly selected. First priority measurements were conducted at the level of individual SMS and used visual soil assessment (VSA) (Shepherd 2000) to score soil porosity and aggregation (1-4 with 1 being the best). Quantitative measurements were made for soil bulk density (Grossman \& Reinsch 1994), water-holding capacity (i.e. soil water content at field capacity) and earthworm populations (Fraser et al. 1996). Soil texture was characterised for every SMS using the classical hand rolled-ball technique (Milne et al. 1995).

Soil fertility and biological analyses were conducted on a bulked sample of soil from the three SMS within each MU. Soil samples were collected from the standard sampling depths for pasture $(0-7.5 \mathrm{~cm})$. Soil chemical analyses included $\mathrm{pH}$, Olsen-P, resin-P, sulphate-S, organic-S, exchangeable cations, potentially mineralisable-N, organic- $\mathrm{C}$, total- $\mathrm{N}$, cation exchange capacity (CEC) and $\mathrm{P}$ retention capacity (Blakemore et al. 1987), whilst biological measurements included $0.5 \mathrm{M}$ $\mathrm{K}_{2} \mathrm{SO}_{4}$-soluble C (Matlou \& Haynes 2006), soil microbial biomass (SMB) C and N (Jorgenson 1995a; Jorgenson 1995b) and basal respiration (Kelliher et al. 2005).

\section{Statistical analysis}

Quantitative data was analysed using a mixed model fitted with restricted maximum likelihood (REML) using GenStat v.12 (GenStat Committee 2009). This method allowed analysis of the entire data-set simultaneously, even though the data was not balanced and there were several gaps where data for some variables was not collected over all the sampling rounds.

A measure of the variability associated with the predicted means is provided by the approximate Least significant differences (LSD). LSDs are provided at the $5 \%$ level with $\mathrm{t}=2$ ( $\mathrm{t}$ is justifiable since the data set is large; $>500$ observations). Where necessary a (natural) $\log$ transformation was used to ensure equal variances in the analysis. In this situation, the back transform of the LSD should be interpreted as the Least Significant Ratio (5\%). The data was arranged in a hierarchical structure with each fixed effect being assessed at different strata (different levels of random effects) i.e. random effects = cluster, property, landform, year; fixed effects $=$ sector, management, landform.

Qualitative data was analysed using a multinomial regression model run in $\mathrm{R}$ Core Development Team (Venables et al. 2008) along a similar hierarchical structure to that of the quantitative analysis but at the individual SMS level.

\section{Results and Discussion \\ Intensification measures}

Dairy EROI values were almost an order of magnitude higher than those for SB and were due to DY energy outputs being 10-20 times greater than for SB whilst inputs were only $2-3 \mathrm{x}$ higher (Table 2). However, not all energy input data was available for the DY farms with inputs restricted to fertiliser, electricity 
and supplementary feed. Those for SB were more comprehensive (Barber \& Lucock 2006; Barber et al. 2008; Wells 2001) but Wells (2001) compiled such a list for DY within New Zealand and our estimate is that DY inputs are actually about $30-40 \%$ higher for most farms on the same basis. This reduces DY EROI values accordingly but would still mean values at least 5 times greater than SB. This was used as our main indicator for increased intensity of production between sectors.

Organic producers generally had lower energy inputs and outputs than the other management systems although these were not significantly different within each sector and did not measurably result in greater efficiency. In terms of imported nutrient use, SB organic was the lowest user, averaging $13 \mathrm{~kg} / \mathrm{ha}(\mathrm{P}, \mathrm{K}$ and S) annually compared with 80 and $60 \mathrm{~kg} / \mathrm{ha}(\mathrm{N}, \mathrm{P}$, $\mathrm{K}$ and S) for integrated and conventional, respectively. DY organic averaged $\sim 110 \mathrm{~kg} / \mathrm{ha}$ annually $(\mathrm{N}, \mathrm{P}, \mathrm{K}$ and $\mathrm{S})$ compared with twice that for conventional.

\section{Soil fertility}

Olsen-P, resin-P and sulphate-S values were significantly $(\mathrm{P}<0.001)$ lower for SB than for DY (Table 3 ) reflecting the total amounts of imported nutrients applied but some small amount of variance could also be attributed to differences in soil order (Sparling \& Schipper 2002). Similarly, within each sector, the differential application rates between managements systems meant the organic panel values were consistently lower than those for conventional and integrated $(\mathrm{P}<0.01)$ (Table $3)$. In $\mathrm{SB}$, mean organic panel values were lower than optimum (P 20-30; S 10-12) for New Zealand pastures
(Roberts et al. 1994) whilst, conversely, Olsen-P values for conventional DY were about $50 \%$ higher on average than the top of the recommended optimal range (20-40).

Sheep and beef, as the most extensive of our pastoral sectors, relies on modest fertiliser use, mainly superphosphate, to underpin clover growth and $\mathrm{N}$ fixation (Morton et al. 1994). Consequently, soil fertility values for SB tend to be at the lower end although in this group only organic-S appears to be less than optimal (Morton et al. 1994). Conversely, DY P and S values are around twice those of SB and reflect a policy to maximise production from smaller pastoral areas by ensuring major nutrients are adequate. Olsen-P values for DY conventional are well above the recommended optimal range and these have the capacity to lead to water quality issues from farmland runoff (McDowell et al. 2001; Watson et al. 2002; Wilcock 1986; Wilcock et al. 2006).

Soil $\mathrm{pH}$, cation and total base saturation (BS) values were highest for DY but not CEC. Although most of the DY cluster were on allophanic soils with high $\mathrm{pH}$ and a moderate-to-strong variable-charge component (Theng 1980), SB clusters were dominated by twice as many finer textured clay loams as DY (Fig. 1). Consequently, SB clusters generally had higher CECs despite (slightly) lower $\mathrm{pH}$. Between sectors there were several system interactions with SB Organic having lower $\mathrm{CEC}$ and $\mathrm{BS} \%$ values than either conventional/ integrated but not for DY (Table 3). Greater use of nitrogen fertiliser and higher animal stocking rates on DY conventional farms may explain this difference through greater acidification and cation leaching rates.

Table 3 REML mean and statistics for inorganic soil fertility and physical analyses for panels of both DY and SB sectors. Brackets denote natural log-transformed data.

\begin{tabular}{|c|c|c|c|c|c|c|c|c|c|c|c|c|c|c|c|c|}
\hline Sector- & Olsen-P & Resin-P & SO4-S & $\mathrm{pH}$ & CEC & $\mathrm{Ca}$ & $\mathrm{Mg}$ & $\mathrm{K}$ & $\mathrm{Na}$ & & se st & turati & on (\% & & $\mathrm{SBD}^{\mathrm{b}}$ & $\mathrm{SMC}^{\mathrm{b}}$ \\
\hline Panel & $\begin{array}{c}\mathrm{mg} \mathrm{P} / \mathrm{L} \\
\text { soil }\end{array}$ & $\begin{array}{c}\mathrm{mg} \mathrm{P} / \mathrm{L} \\
\text { soil }\end{array}$ & $\begin{array}{c}\mathrm{mg} \mathrm{S} / \mathrm{L} \\
\text { soil }\end{array}$ & & & & $\mathrm{cmol}^{+} / \mathrm{Ls}$ & & & Total & $\mathrm{Ca}$ & $\mathrm{Mg}$ & $\mathrm{K}$ & $\mathrm{Na}$ & $\mathrm{g} / \mathrm{cm}^{3}$ & $\% w / w$ \\
\hline DY-Org. & 49 & $83(4.42)$ & 15 (2.69) & 6.2 & 17.6 & 11.2 & $1.5(0.41)$ & $0.9(-0.16)$ & 0.2 & 77 & 61 & 9.6 & 5.4 & 1.3 & 0.77 & 0.55 \\
\hline DY-Conv. & 59 & $103(4.63)$ & $20(2.97)$ & 6.0 & 16.4 & 9.5 & $1.3(0.24)$ & $0.8(-0.26)$ & 0.2 & 72 & 57 & 6.2 & 5.3 & 1.2 & 0.78 & 0.54 \\
\hline SB-Org. & 13 & $28(3.35)$ & $9(2.13)$ & 5.9 & 18.0 & 10.0 & $1.8(0.60)$ & $0.7(-0.36)$ & 0.3 & 70 & 52 & 11.4 & 4.5 & 1.7 & 1.14 & 0.36 \\
\hline SB-Integ. & 22 & $51(3.94)$ & 15 (2.68) & 5.8 & 20.5 & 12.0 & $1.9(0.66)$ & $0.9(-0.16)$ & 0.3 & 75 & 57 & 11.6 & 4.8 & 1.6 & 1.17 & 0.33 \\
\hline SB-Conv. & 22 & 54 (3.98) & $18(2.87)$ & 5.9 & 19.5 & 12.5 & $1.6(0.46)$ & $0.7(-0.37)$ & 0.3 & 74 & 60 & 8.5 & 4.2 & 1.5 & 1.14 & 0.36 \\
\hline Sector & *** & $* \star *$ & $\star \star \star *$ & 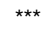 & NS & NS & *** & NS & *** & NS & * & $\star \star \star *$ & $\star \star$ & $\star \star \star *$ & 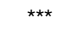 & *** \\
\hline Panel & $* \star *$ & ** & $\star \star$ & * & * & NS & * & NS & NS & NS & NS & $\star \star \star *$ & NS & NS & NS & NS \\
\hline$S^{*} P$ & NS & NS & NS & NS & * & * & NS & NS & NS & * & * & NS & NS & NS & NS & NS \\
\hline${ }^{\mathrm{a}} \mathrm{LSD}_{\mathrm{sp}}$ & 7 & $(0.29)$ & $(0.30)$ & 0.1 & 2.4 & 2.0 & $(0.2)$ & $(0.2)$ & 0.1 & 6 & 8 & 1.4 & 1.0 & 0.3 & 0.08 & 0.07 \\
\hline
\end{tabular}

\footnotetext{
${ }^{a}$ average LSD for sector ${ }^{\star}$ panel interactions. Bracketed values $(x)$ are LSD values for log-transformed means. ${ }^{b} 0-15 \mathrm{~cm}$ depth.
} 
Figure 1 Mean soil texture classification for $A$ and $B$ horizons for SB and DY sectors; (Key for soil orders: $\mathrm{C}=$ clay, $\mathrm{CL}=$ clay loam, $\mathrm{ZCL}=$ silt clay loam, $\mathrm{SCL}=$ sandy clay loam, $\mathrm{ZL}=$ silt loam, $\mathrm{SL}=$ sandy loam).

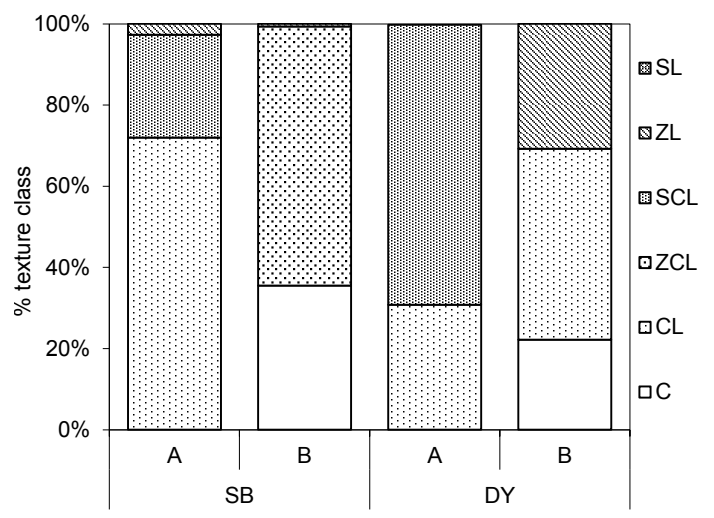

Soil organic matter (SOM) values for $\mathrm{C}$ and $\mathrm{N}$ were greater on average for DY than SB but no significant differences were recorded between panels for either sector (Table 4). Differences between sectors are more likely founded in the soil order and the greater number of DY clusters on allophanic soils rather than landuse per se (Sparling \& Schipper 2002) (Table 4). With DY organic farms, the younger of the two sectors in their establishment, and $50 \%$ of farms still to reach accreditation at the time of sampling, there may be further changes in soil properties still to occur. Schipper et al. (2007) has documented a gradual loss of soil carbon from some New Zealand soils, especially pastures, in the past 20 years. Whether this process is related to increased intensification of land use and whether DY organic farming will slow or even reverse this process will require further longitudinal monitoring.

Although soil $\mathrm{C}$ and $\mathrm{N}$ values between panels did not differ significantly for any sector, $\mathrm{C} / \mathrm{N}$ ratios did for both sectors $(\mathrm{P}<0.001)$ and panels $(\mathrm{P}<0.05)$ (Table 4$)$. The more intensive use of $\mathrm{N}$ fertilisers and greater stocking rates in DY probably explains most of this between sector variation. Higher soil $\mathrm{C} / \mathrm{N}$ ratios for Organic panels convey that, without applied external $\mathrm{N}$, organic returns will also have higher $\mathrm{C} / \mathrm{N}$ ratios and therefore, less $\mathrm{N}$ is being cycled overall. Potentially (anaerobic) mineralisable-N $(\mathrm{AMN})$ values were greater $(\mathrm{P}<0.001)$ for DY but whilst there was no overall management effect, there was a sector-by-panel interaction for SB, where organic was lower than conventional $(\mathrm{P}<0.05)$. Whilst this may be due to not using any $\mathrm{N}$ fertilisers it may also reflect less than optimal $\mathrm{P}$ and $\mathrm{S}$ for some of these farms and reduced legume vigour (During 1984). When AMN values were expressed on a soil-N basis these trends were still evident if not significant (Table 4).

\section{Soil biological condition}

Earthworm numbers and weights were similar between DY and SB and across panels but there was an interaction $(\mathrm{P}<0.05)$ in earthworm numbers between sectors with DY organic having greater worm numbers than conventional but not for SB where organic and conventional were similar (integrated had the lowest numbers; Table 5). There was no increase in earthworm weights between DY and SB panels that suggests that although worm numbers were about $20 \%$ greater under DY organic they were individually smaller, which might reflect fewer available food sources but lower treading effects from reduced stocking rates.

Soluble-C, basal respiration and metabolic quotient values were higher $(\mathrm{P}<0.001)$ for $\mathrm{DY}$ than for $\mathrm{SB}$ but when SMB-C, $\mathrm{N}$ and basal respiration were calculated

Table 4 REML statistics for soil organic matter fertility analyses for each panel of DY and SB sectors. Brackets denote natural log-transformed data.

\begin{tabular}{|c|c|c|c|c|c|c|c|}
\hline \multirow{2}{*}{$\begin{array}{l}\text { Sector- } \\
\text { Panel }\end{array}$} & $\mathrm{C}$ & $\mathrm{N}$ & \multirow{2}{*}{$\begin{array}{l}\mathrm{C} / \mathrm{N} \\
\text { ratio }\end{array}$} & \multicolumn{2}{|c|}{ Organic-S } & \multicolumn{2}{|c|}{$\mathrm{AMN}^{\mathrm{a}}$} \\
\hline & \multicolumn{2}{|c|}{$\% w / v$} & & $\mathrm{mg} \mathrm{S} / \mathrm{L}$ soil & $\mathrm{mg} \mathrm{S} / \mathrm{kg}$ soil-C & $\mathrm{kg} \mathrm{N} / \mathrm{ha}$ & $\mathrm{mg} \mathrm{N} / \mathrm{kg}$ soil- $\mathrm{N}^{\mathrm{c}}$ \\
\hline DY-Org & 6.7 & 0.65 & 10.3 & $9.3(2.23)$ & 133 & 294 & 25 \\
\hline DY-Conv & 6.5 & 0.64 & 10.0 & $9.0(2.20)$ & 140 & 287 & 25 \\
\hline SB-Org & 4.8 & 0.44 & 11.0 & $5.3(1.66)$ & 132 & 184 & 33 \\
\hline SB-Integ & 5.1 & 0.48 & 10.7 & $6.0(1.79)$ & 143 & 207 & 34 \\
\hline SB-Conv & 5.2 & 0.48 & 10.9 & $6.5(1.87)$ & 147 & 214 & 35 \\
\hline Sector & 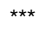 & 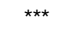 & $\star \star \star *$ & $* \star \star$ & NS & 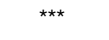 & *** \\
\hline Panel & NS & NS & * & NS & NS & NS & NS \\
\hline $\mathrm{S}^{*} \mathrm{P}$ & NS & NS & NS & NS & NS & * & NS \\
\hline${ }^{\mathrm{b}} \mathrm{LSD}_{\mathrm{sp}}$ & 0.7 & 0.06 & 0.3 & $(0.22)$ & 27 & 30 & 3 \\
\hline
\end{tabular}

${ }^{a} \mathrm{AMN}=$ anaerobic mineralisable- $\mathrm{N}$; ${ }^{b}$ average LSD for sector ${ }^{*}$ panel interactions;

Bracketed values $(x)$ are LSD values for log-transformed means $(x)$ 
Table 5 REML statistics for earthworms and soil microbial analyses for each panel of KF, DY and SB sectors. Brackets denote natural log-transformed data.

\begin{tabular}{|c|c|c|c|c|c|c|c|c|c|c|c|c|}
\hline Sector- & Earth & Norms & Solut & ole-C & Soil micr & robial-C & Soil mic & robial-N & Microbial & Basal re & spiration & Metabolic-Q. \\
\hline Panel & No. $/ \mathrm{m}^{2}$ & Wgt $\mathrm{g} / \mathrm{m}^{2}$ & $\begin{array}{c}\mathrm{mg} \mathrm{C} / \mathrm{L} \\
\text { soil }\end{array}$ & $\begin{array}{l}\mathrm{g} \mathrm{C} / \mathrm{kg} \\
\text { soil-C }\end{array}$ & $\underset{\text { soil }}{\mathrm{mg} \mathrm{C} / \mathrm{L}}$ & $\begin{array}{l}\mathrm{g} \mathrm{C} / \mathrm{kg} \\
\text { soil-C }\end{array}$ & $\underset{\text { soil }}{\mathrm{mg} \mathrm{N} / \mathrm{L}}$ & $\begin{array}{l}\mathrm{mg} \mathrm{N} / \mathrm{kg} \\
\text { soil- } \mathrm{N}^{\mathrm{b}}\end{array}$ & $\mathrm{C} / \mathrm{N}$ ratio & $\begin{array}{l}\mathrm{mg} \mathrm{CO}_{2} / \mathrm{L} \\
\text { soil/day }\end{array}$ & $\begin{array}{l}\mathrm{mg} \mathrm{CO}_{2} / \mathrm{kg} \\
\text { soil-C/day }\end{array}$ & $\begin{array}{l}\mathrm{mg} \mathrm{CO}_{2} / \mathrm{g} \\
\mathrm{SMC} / \mathrm{min}\end{array}$ \\
\hline DY-Org. & $\begin{array}{c}524 \\
(6.26)\end{array}$ & $\begin{array}{c}216 \\
(5.46)\end{array}$ & 247 & 3.0 & 993 & 15.2 & $\begin{array}{c}194 \\
(5.27)\end{array}$ & $\begin{array}{c}31 \\
(3.44)\end{array}$ & $\begin{array}{c}4.6 \\
(1.52)\end{array}$ & $85(4.45)$ & 709 (6.56) & 88.6 \\
\hline $\begin{array}{l}\text { DY- } \\
\text { Conv. }\end{array}$ & $\begin{array}{c}401 \\
(5.99)\end{array}$ & $\begin{array}{c}232 \\
(5.56)\end{array}$ & 262 & 3.1 & 886 & 13.7 & $\begin{array}{c}195 \\
(5.27)\end{array}$ & $\begin{array}{c}31 \\
(3.43)\end{array}$ & $\begin{array}{c}4.1 \\
(1.42)\end{array}$ & $73(4.30)$ & $688(6.53)$ & 98.7 \\
\hline SB-Org. & $\begin{array}{c}502 \\
(6.22)\end{array}$ & $\begin{array}{c}208 \\
(5.22)\end{array}$ & 127 & 2.9 & 1044 & 21.5 & $\begin{array}{c}182 \\
(5.20)\end{array}$ & $\begin{array}{c}44 \\
(3.77)\end{array}$ & $\begin{array}{c}5.1 \\
(1.62)\end{array}$ & $43(3.76)$ & $\begin{array}{l}1220 \\
(7.11)\end{array}$ & 73.5 \\
\hline $\begin{array}{l}\text { SB- } \\
\text { Integ. }\end{array}$ & $\begin{array}{c}425 \\
(6.05)\end{array}$ & $\begin{array}{c}207 \\
(5.27)\end{array}$ & 129 & 3.0 & 1167 & 22.6 & $\begin{array}{c}209 \\
(5.34)\end{array}$ & $\begin{array}{c}44 \\
(3.79)\end{array}$ & $\begin{array}{c}5.2 \\
(1.64)\end{array}$ & 39 (3.65) & $\begin{array}{l}1053 \\
(6.96)\end{array}$ & 60.1 \\
\hline $\begin{array}{l}\text { SB- } \\
\text { Conv. }\end{array}$ & $\begin{array}{c}599 \\
(6.39)\end{array}$ & $\begin{array}{c}283 \\
(5.38)\end{array}$ & 135 & 2.9 & 1023 & 20.0 & $\begin{array}{c}183 \\
(5.21)\end{array}$ & $\begin{array}{c}49 \\
(3.67)\end{array}$ & $\begin{array}{c}5.1 \\
(1.62)\end{array}$ & $37(3.60)$ & 981 (6.89) & 56.5 \\
\hline Sector & NS & NS & *** & NS & ** & 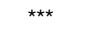 & NS & *** & ** & *** & *** & 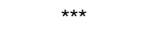 \\
\hline Panel & * & NS & NS & NS & * & * & NS & NS & NS & NS & * & NS \\
\hline$S^{\star} P$ & NS & NS & NS & NS & NS & NS & NS & NS & NS & NS & NS & NS \\
\hline${ }^{\mathrm{b}} \mathrm{LSD}_{\mathrm{sp}}$ & $(0.32)$ & $(0.34)$ & 23 & 0.4 & 132 & 2.2 & $(0.26)$ & $(0.22)$ & $(0.17)$ & $(0.23)$ & $(0.22)$ & 23 \\
\hline
\end{tabular}

${ }^{\text {a SMC }}=$ soil microbial carbon; ${ }^{b}$ average LSD for sector ${ }^{\star}$ panel interactions; Bracketed values $(x)$ are LSD values for log-transformed means.

on a soil $\mathrm{C}$ or $\mathrm{N}$ basis, values were substantially lower than the equivalent $\mathrm{SB}$ values $(\mathrm{P}<0.01)$ (Table 5). This is probably due to a large part of the SOM held in allophanic soils being stabilised by the clay minerals allophane and ferrihydrite, which resists degradation by soil micro-organisms (Parfitt et al. 1997). These soils make up the majority of the DY clusters and consequently, a greater proportion of total soil carbon is in these forms as compared with SB soils and is not a major contributor to soil biological respiration. Higher soluble-C and metabolic quotient values for DY probably reflects the higher excreta returns and increased respiration as a result (Table 5).

Panel differences were restricted to $\mathrm{SB}$ and values for SMB-C $(\mathrm{P}<0.05)$ and basal respiration (per unit soil-C; $\mathrm{P}<0.05$ ). Greater SMB-C for integrated (and $\mathrm{N}$ to a lesser extent) over organic/conventional may simply reflect the lower $\mathrm{C} / \mathrm{N}$ ratios of organic returns. It is tenuous to make a firm explanation for the higher respiration rate per unit soil-C for SB organic but this may be related to increased microbial stress and higher soil $\mathrm{C} / \mathrm{N}$ ratios of the organic returns. Further monitoring and investigation is required.

\section{Soil physical condition}

VSA scores for soil porosity $(\mathrm{P}<0.05$; Fig. 2$)$ and aggregation $(\mathrm{P}<0.05)$ were ranked highest overall for SB with most scores ranked "very good-to-excellent". Physical condition for DY overall, however, was still ranked "good". Qualitative measures for porosity and aggregation using VSA scoring have been shown to have a strong relationship with macroporosity and aggregate mean weight diameter measurements, respectively (Shepherd 2003). Just under $20 \%$ of DY, and $4 \%$ of SB porosity scores were ranked "fair" or "bad", a rating that ranks below the macroporosity value of $10 \%$, the accepted margin for optimal maintenance of pasture production (Drewry et al. 2008). There were no significant differences in porosity or aggregation scoring between panels for either DY or SB.

Soil bulk density (SBD) values were greatest for SB and lowest for DY $(\mathrm{P}<0.001)$, a characteristic largely attributable to soil order (Sparling \& Schipper 2002) (Table 3). However, about $30 \%$ of variation is still attributable to land use and it expected that treading effects and higher stocking rates for DY would increase SBD, comparatively, over SB. Soil moisture content (SMC) at field capacity inversely mirrored SBD with higher moisture contents under DY than SB (Table $3)$. There were no strong differences between DY and SB panels for organic and conventional/integrated but with many of the DY farms still undergoing transition to organic there may be some further divergence with changes in stocking rates. With soil physical condition for DY still ranked good, however, there may be few further beneficial effects to be gained from organic production.

\section{Principal component analysis}

Principal component analysis was initially done using 25 variables spread evenly between soil fertility, physical and biological condition and SOM. There were no particularly strong factors identified in the analysis and we did not attempt to reduce the data set further as 
Figure 2 Soil porosity score distribution for each panel DY and SB sectors. An asterisk denotes a significant difference $(P<0.05)$ in scores at an individual level or cross-sector basis (NS; not significant).

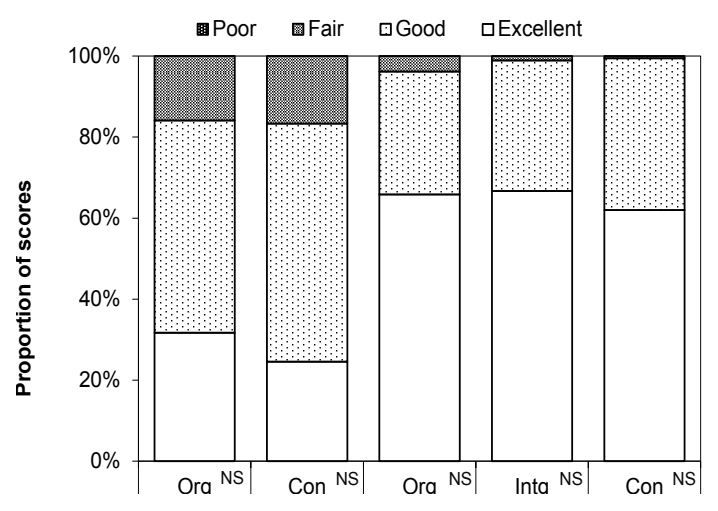

its purpose was to judge how similar each sector and panel were to the others. The $x$ (PC1) and $y$ (PC2) axes accounted for $75 \%$ and $12 \%$, respectively, of the total variation. Principal component 1 mainly accounted for SOM, biological and physical condition variables and the second component mainly fertility variables.

Principal component scores found that although there was some separation between panels, the bulk of the variability was between sectors i.e. land-use and soil order were larger sources of variation than management systems. The greatest separation between panels was in the second component and mainly related to differences in soil fertility. These findings seem consistent with the study of Sparling \& Schipper (2002) that showed differences in soil properties can largely be attributed to land-use and soil order or geomorphology although management system was not specifically investigated.

\section{Conclusions}

Our comparison of soil properties between sheep and beef and dairy sectors showed that although there were large differences in energy inputs and EROI values, there were few differences that indicated these increased with an increase in farming intensity. A greater number of differences in soil properties were observed in response to management effects between organic and conventional/integrated systems across both sectors, mainly those related to soil fertility. Most of the overall difference in soil properties found between sectors and panels was due to soil order and land-use characteristics rather than management system effects. With DY Organic an establishing group, further differences in soil properties between organic and conventional panels may still yet develop.
Figure 3 Principal components analysis of mean soil property values for SB and DY sectors. Values on $x(P C 1)$ and $y(P C 2)$ axes denote the percentage of total variation explained by each component.

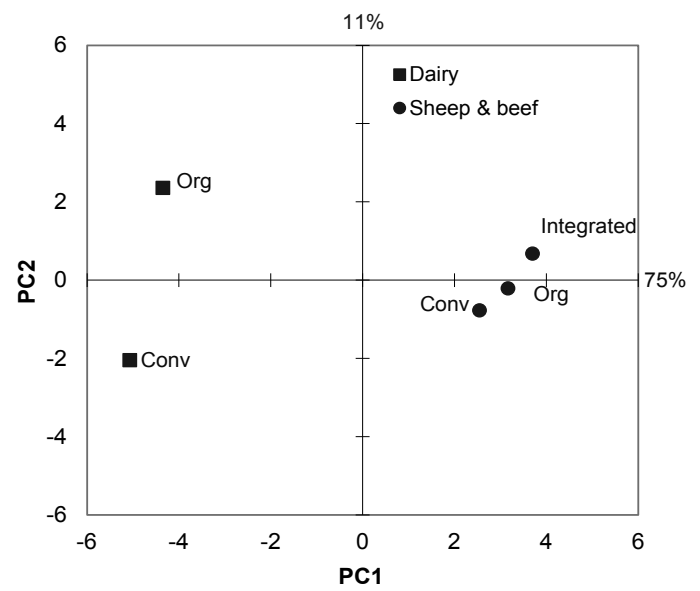

\section{ACKNOWLEDGEMENTS}

We wish to thank Dr Jeff Reid, Andrea Pearson and Duncan Hedderley of Plant and Food Research (fromerly Crop and Food) who were instrumental in setting the original sampling protocol of the ARGOS program and its statistical analysis (D. Hedderley). We are grateful to the farmers who allowed us access to their land and Lesley Hunt of Lincoln University for advice on statistical analysis. The study was funded by the New Zealand Foundation for Research, Science and Technology (FRST) through the Agricultural Research Group on Sustainability (ARGOS).

\section{REFERENCES}

Barber, A.; Lucock, D. 2006. Total Energy Indicators: Benchmarking Organic, Integrated and Conventional Sheep and Beef Farms. Report No. 06/07. Agricultural Research Group on Sustainability.

Barber, A.J.; Pellow, G.M.; Christie, R.G.; Van Bysterveldt, A.M. 2008. Greenhouse gas assessment for the Lincoln University Dairy Farm. Proceedings of the New Zealand Grassland Association 70: 69-75.

Blakemore, L.C.; Searle, P.L.; Daly, B.K. 1987. Methods for Chemical Analysis of Soils. Report No. 80. NZ Soil Bureau.

Coetzer, E. 2010. GlobalG.A.P. Standards. GlobalGAP, Cologne.

Drewry, J.J.; Cameron, K.C.; Buchan, G.D. 2008. Pasture yield and soil physical property responses to soil compaction from treading and grazing - a review. Australian Journal of Soil Research 46: 237-256.

During, C. 1984. Fertilisers and soils in New Zealand farming. NZ Government Printer, Wellington. 361 pp.

Fraser, P.M.; Williams, P.H.; Haynes, R.J. 1996. 
Earthworm species, population size and biomass under different cropping systems across the Canterbury Plains, New Zealand. Applied Soil Ecology 3: 49-57.

GenStat Committee 2009. The Guide to GenStat Release12 - Parts 1-3. Report VSN International.

Grossman, R.B.; Reinsch, T.G. 1994. Bulk density and linear extensibility. pp. 201-225. In: Methods of Soil Analysis. Part 4. Physical Methods. Eds. Dane, J. H.; Topp, G. C. Soil Science Society of America, Madison, Wisconsin.

Jorgenson, R.G. 1995a. Microbial activity - The fumigation extraction method. pp. 382-384. In: Methods in Applied Soil Microbiology and Biochemistry. Eds. Alef, K.; Nannipieri, P. Academic Press, London.

Jorgenson, R.G. 1995b. Microbial activity - The fumigation extraction method for microbial biomass nitrogen. pp. 388-389. In: Methods in Applied Soil Microbiology and Biochemistry. Eds. Alef, K.; Nannipieri, P. Academic Press, London.

Kelliher, F.M.; Sedcole, J.R.; Minchin, R.F.; Wan, Y.; Condron, L.M.; Clough, T.J.; Bol, R. 2005. Soil microbial respiration responses to repeated urea applications in three grasslands. Australian Journal of Soil Research 43: 905-913.

Matlou, M.C.; Haynes, R.J. 2006. Soluble organic matter and microbial biomass $\mathrm{C}$ and $\mathrm{N}$ in soils under pasture and arable management and the leaching of organic C, N and nitrate in a lysimeter study. Applied Soil Ecology 34: 160-167.

McDowell, R.W.; Sharpley, A.N.; Brookes, P.C.; Poulton, P. 2001. Relationship between soil test phosphorus and phosphorus release to solution. Soil Science 166: 137-149.

Milne, J.D.G.; Clayden, B.; Singleton, P.L.; Wilson, A.D. 1995. Particle-size distribution. pp. 45-49. In: Soil Description Handbook. Manaaki Whenua Press, Christchurch.

Morton, J.; Roberts, A.H.C.; Edmeades, D.C. 1994. Fertiliser use on sheep and beef farms. New Zealand Fertilisers Manufacturers Research Association and New Zealand Pastoral Agriculture Research Institute Ltd, Hamilton. 38 pp.

Norton, S.; Lucock, D.; Moller, H.; Manhire, J. 2010. Energy return on investment for dairy and sheep/ beef farms under conventional, integrated or organic management. Proceedings of the New Zealand Grassland Association 72: xxx-xxx.

Parfitt, R.L.; Theng, B.K.G.; Whitton, J.S.; Shepherd, T.G. 1997. Effects of clay minerals and land use on organic matter pools. Geoderma 75: 1-12.
Roberts, A.H.C.; Morton, J.; Edmeades, D.C. 1994. Fertiliser use on dairy farms (Lower North Island and South Island). Dairying Research Corporation Ltd and New Zealand Pastoral Agriculture Research Institute Ltd, Hamilton. 36 pp.

Schipper, L.A.; Baisden, W.T.; Parfitt, R.L.; Ross, C.; Claydon, J.J.; Arnold, G. 2007. Large losses of soil $\mathrm{C}$ and $\mathrm{N}$ from soil profiles under pasture in New Zealand during the past 20 years. Global Change Biology 13: 1138-1144.

Shepherd, T.G. 2000. Visual Soil Assessment. Volume 1. Field guide for cropping and pastoral grazing on flat to rolling country. Landcare Research, Palmerston North. 84 pp.

Shepherd, T.G. 2003. Assessing soil quality using visual soil assessment. In: Tools for nutrient and pollution management. Occasional Report No. 17. pp. 153166. Eds. Currie, L. D.; Hanly, J. A. Fertiliser and Lime Research Centre, Palmerston North.

Sparling, G.P.; Schipper, L.A. 2002. Soil Quality at a National Scale in New Zealand. Journal of Environmental Quality 31: 1848-1857.

Theng, B.K.G. Ed. 1980. Soils with variable charge. NZ Soil Science Society, Palmerston North.

Venables, W.N.; Smith, D.M.; R Core Development team 2008. An introduction to R. UNjobs, Geneva.

Watson, C.A.; Bengtsson, H.; Ebbesvik, M.; Lùes, A.-K.; Myrbeck, A.; Salomon, E.; Schroder, J.; Stockdale, E.A. 2002. A review of farm-scale nutrient budgets for organic farms as a tool for management of soil fertility. Soil Use and Management 18: 264-273.

Wells, C. 2001. Total Energy Indicators of Agricultural Sustainability: Dairy Farming Case Study. Report No. Technical Paper 2001/3. MAF Policy, Ministry of Agriculture and Forestry.

Wilcock, R.J. 1986. Agricultural runoff: a source of water pollution in New Zealand? New Zealand Agricultural Science 20: 98-103.

Wilcock, R.J.; Monaghan, R.M.; Quinn, J.M.; Campbell, A.M.; Duncan, M.J.; McGowan, A.W.; Betteridge, K. 2006. Land use and water quality interactions in an intensive dairying catchment: a review of nine years of monitoring data and development of water quality targets for the Toenepi Stream catchment, New Zealand. New Zealand Journal of Marine and Freshwater Research 40: 123-140. 